\title{
Development Of SMEs In Myanmar In The Globalization Era
}

Balbir B. Bhasin, University of Arkansas, USA

Sivakumar Venkataramany, Ashland University, USA

\begin{abstract}
SMEs are of overwhelming importance to the young and growing economies of most Southeast Asian nations, but this is exceptionally the case for Myanmar. The country is rich with resources but has not managed to rid itself of post colonial mismanagement, socialist and bureaucratic tendencies. This paper evaluates the existing private sector development policy in Myanmar which can only be defined as lacking any substance, coherence and coordination. Myanmar needs to create a meaningful and comprehensive policy for the development of its private sector. This includes trade and investment liberalization and creation of infrastructure. Much can be learned from other members of ASEAN, such as Singapore, Malaysia and Thailand, that have succeeded in similar endeavors.
\end{abstract}

Keywords: Myanmar; SMEs; globalization

\section{INTRODUCTION}

s with most growing economies, Myanmar needs to develop its small and medium sized enterprises (SMEs), which is the key engine for growth for all Southeast Asian countries. Myanmar, formerly known as Burma, is potentially a very wealthy country. With a population in excess of 58 million (2008), it is the largest country in mainland Southeast Asia. It is well endowed with rich natural resources. It has abundant natural gas reserves. It has large areas of arable land, forestry, minerals of numerous varieties, and freshwater and marine resources, yet it remains poor due to isolation and mismanagement. It has seen an average growth rate of only 2.9\%, among the lowest in the region (ADB, 2009). The WTO recognizes Myanmar as one of the least developed countries with its exports at $\$ 6,937$ million and imports at $\$ 4,288$ million for 2008 . The country ranks at 107 among all nations in terms of inward FDI performance. It has received an inward foreign direct investment (FDI) of \$323 million in 2009 which is dwarfed by the South East Asia receiving $\$ 36,806$ million. There is no outward FDI from Myanmar, whereas southeast Asia has made \$21,284 million.

The country's history has seen the unification of three waves of immigration from Cambodia (Hmong), the eastern Himalayas (Mongol) and northern Thailand (Tai) under the Buddhist King Anawratha in the $9^{\text {th }}$ century at Bagan. By the $14^{\text {th }}$ century after numerous invasions by the Mongols, and then by neighboring Siam, the country was carved up among warring tribes. The arrival of Europeans traders in 1824 - Portuguese, Dutch, and British finally resulted in the colonization of Burma by the British in 1937. The British were expelled by the Japanese during the Second World War in 1941. The Japanese surrendered in 1945 and Burma became independent in 1948 under the leadership of their great statesman Aung San, who was assassinated soon the same year. The Union of Burma became a democratic republic with U Nu as Prime Minister.

In 1962, left-wing general Ne Win staged a coup, banned political opposition, suspended the constitution, and introduced the "Burmese way of socialism." After 25 years of economic hardship and repression, the Burmese people held massive demonstrations in 1987 and 1988. These were brutally quashed by the State Law and Order Council (SLORC). In 1989, the military government officially changed the name of the country to Myanmar. The ruling junta has maintained a tight grip on Myanmar since 1988. There have been numerous uprisings against the government in favor of democracy, but they have been ruthlessly put down by the military. 
On May 3, 2008, Cyclone Nargis ravaged the Irrawaddy Delta and Yangon, killing 22,500 people, leaving up to a million homeless, and causing serious damage to the agricultural sector. The major agricultural product is rice, which covers about $60 \%$ of the country's total cultivated land area and accounts for $97 \%$ of total food produced. The agriculture sector accounts for $43 \%$ of GDP, while less than $20 \%$ is industry and the remaining $37 \%$ is services. Seventy percent of the labor force is in agriculture, $7 \%$ in industry and $23 \%$ in services (CIA, 2010). Agricultural products, in addition to rice, are pulses, beans, sesame, groundnuts, sugarcane, hardwood, fish and fish products. Industries are agricultural processing, wood and wood products, mainly from teak, copper, tin, tungsten, iron, cement, pharmaceuticals, fertilizer, oil and natural gas, jade and gems. Other than the state-owned industries, the majority of the industrial sector comprises of SMEs.

\section{BACKGROUND: SME POLICY EVOLUTION IN MYANMAR}

Myanmar's history of economic development since independence can be divided into three distinct periods of political economy:

- 1948 to 1962: Period of parliamentary democracy with a mixed but free economic system

- $\quad 1962$ to 1988: Period of command and socialist economy under military rule

- 1988 onwards: Period of market oriented economy under military rule

The country opened its economy to private investment only in 1988. Prior to this, the Social Economic System existed and everything was controlled by the state. In 1989, the SLORC, later reconstituted as the State Peace and Development Council (SPDC), allowed private sector businesses to "engage in external trade and to retain export earnings and started to legitimize and formalize border trade with neighboring countries, hitherto an activity that had been deemed illegal" (Kudo and Mieno, 2007). A modest expansion of the private sector was permitted and some foreign investment was allowed. Priorities set were development of agriculture as the base to support development of other sectors, proper evolution into a market-oriented economic system, invite investment and technical participation from internal and external sources, and initiative and control to remain in the hands of the state. Economic reform measures for various sectors were aimed at adopting a market oriented system for allocation of resources and distribution of goods and services, encouraging private investments and entrepreneurial activities domestically, and opening the country to foreign direct investment; and promoting exports responsibility for implementing the industrial policy was put in the hands of the Myanmar Industrial Development Committee (MIDC).

Traditional enterprises have long existed in Myanmar. They were small cottage industries engaging in handicrafts, textile manufacturing, weaving, jewel cutting and polishing, lacquer ware, wood works, gold, silver and blacksmithing. During the colonial period, the British did not promote the establishment of industries for manufacturing consumer goods, and domestic industries did not get any assistance from the government. Consequently, local industries were concentrated in agriculture and resource-based industries like rice mills and sewing mills (Aung Kyaw, 2008). After independence, the Anti-Fascist People's Freedom League (AFPFL) government welcomed private sector and foreign investment. Private industries flourished parallel to public sector factories. Most large-scale industries were run by the state. The government provided some incentives for SMEs in the form of financing and supply of raw materials. Consequently, by the 1960s, SMEs had achieved considerable progress in food, garment, weaving, cosmetics, chemicals, and consumer goods, such as toys, soap, food snacks, and clothing industries. Ultimately, licenses to build factories had to be restricted as state-owned companies were unable to compete. Records in 1961-1962 show that $91 \%$ of registered companies were owned by Myanmar nationals, up from $86 \%$ in 1953-1954. Joint ownership with foreign nationals increased only from $4.5 \%$ to $5.5 \%$. This was the direct result of the indigenization trend set after independence. The boom in private enterprise came to an end when the military took over in 1962. The Revolutionary Council declared the implementation of the socialist economic system and all significant private businesses were nationalized.

This system led to deterioration of the economic system and limited reforms had to be made in the 1970s. The Right of Private Enterprises Law was enacted in 1977. It recognized the legal status of private enterprises and allowed them to perform specified economic activities. However, private investments during the socialist period were limited to small-scale industries. The role of SMEs was subordinate to state-owned companies and 
cooperatives. Only in 1988 did the SLORC reverse the trend and adopted the market-oriented economic system. The Private Industries Enterprises Law was enacted in 1990, the Promotion of Cottage Industrial Law in 1991, and the Myanmar Citizen's Investment Law in 1994 to boost private business enterprises. The Union of Myanmar Chamber of Commerce and Industry, established in 1989, was upgraded to the Union of Myanmar Federation of Chambers of Commerce and Industry (UMFCCI) in 1999 (Aung Kyaw, 2008). By 2004, SMEs in Myanmar accounted for 92.6\% of the total industrial sector, while large industries for only 7.4\% (Mandal, 2007). Classification of industries by the government of Myanmar was formalized by the Private Industrial Enterprises Law of 1990 and is based on power used, number of employees, capital, and production as shown in Table 1.

By 2007, membership of the UMFCCI had reached 16,363 - comprising of 10,854 local companies, 1,656 enterprises, 770 foreign companies, 185 cooperatives, and 2,898 individual members. SMEs today dominate most of Myanmar's economic activity, accounting for $90 \%$ of the industrial sector and $99 \%$ of manufacturing sector (Tin Maung, 2007).

Table 1: Classification of Industries in Myanmar

\begin{tabular}{|c|l|c|c|c|}
\hline No. & \multicolumn{1}{|c|}{ Category } & Small & Medium & Large \\
\hline 1 & Power used (in horsepower) & 3 to 25 & Over 25 to 50 & Over 50 \\
\hline 2 & Number of workers & 10 to 50 & Over 50 to 100 & Over 100 \\
\hline 3 & Capital outlay in millions of kyat & Up to 1 & Over 1 to 5 & Over 5 \\
\hline 4 & Production value per year (mil k) & Up to 2.5 & Over 2.5 to 10 & Over 10 \\
\hline
\end{tabular}

Source: Union of Myanmar Federation of Chambers of Commerce and Industry (2005) as quoted in Kan Zaw (2006)

\section{LITERATURE REVIEW - SME POLICY AND PERFORMANCE IN MYANMAR}

The MIDC policy guidelines for the development of SMEs, as well as the industrial structure, are based on the principles (Kan Zaw, 2006) of development of industries with agriculture as the base, enhancement of quantity and equality of industrial products, increased production of new types of machinery and equipment, production of machinery and equipment for industrial use, and creation of suitable conditions for a shift to an industrialized state. There are numerous government departments, agencies and institutions promoting SME development in Myanmar, some of which are listed below (Kan Zaw, 2006; Khin and Htwe, 2007):

- $\quad$ Committee for Industrial Development (CID) headed by the Prime Minister

- $\quad$ Myanmar Industrial Development Committee (MIDC) headed by the Minister for Industry (1)

- $\quad$ Myanmar Industrial Development Working Committee (MIDWC) headed by Minister for Industry (2)

- $\quad$ Small-scale Industries Development Sub-committee under the MIDC

- $\quad$ Directorate of Industrial Supervision and Inspection under the Ministry of Industry (1)

- $\quad$ Directorate of Myanmar Industrial Planning under the Ministry of Industry (2)

- 10 Subcommittees headed by the Deputy Minister of the related ministry

- $\quad$ Industrial Zone Supervisory and Management Committees headed by regional district authorities

- $\quad$ Myanmar Industries Association under the UMFCCI

- $\quad$ Small and Medium Enterprises Committee of the Myanmar Engineering Society

Human resource development programs, for supporting SME development, is the responsibility of various government ministries, which include the Ministry of Science and Technology, the Ministry of Industry the Ministry of Cooperatives, and the Ministry of Education. Sharing this responsibility is the UMFCCI and other NGOs. Myanmar also works, to a limited extent, with external organizations, such as the United Nations Development Program (UNDP), Japan External Trade Organization (JETRO), and the Myanmar-Japan Association (Kan Zaw, 2006). Table 2 shows the number of enterprises in Myanmar in 2004.

Very limited research has been done on SME development though it is the main structure of the Myanmar economy. A closed economy - that which is seen as being flawed - recently opened to private enterprise. Not being connected to the global economy, there is little scope for growth and development. In such an environment, the resources available are also limited and expertise in technology, management, distribution, quality control, and 
export is scarce indeed. Aung Kyaw (2008) studied the policies relating to financing of SMEs in Myanmar for the Institute of Developing Economies. He concludes:

Today, the role of SMEs (in Myanmar) has become more vital in strengthening national competitive advantage and the speedy economic integration into the ASEAN region. However, studies show that SMEs have to deal with a number of constraints that hinder their development potential, such as shortage in power supply, availability of long-term credit from external sources, and many others.

Among the problems and constraints cited as impediments to growth were poor infrastructure, resulting in shortage of electricity, weak telecommunications and transportations systems, weak drainage and sewage systems, and limited space. There was also a shortage of spare parts and raw materials, low level of technology, insufficient machines and equipment, lack of capital, and shortage of foreign currency. The number of registered enterprises is presented in Table 2 .

Table 2: Number of Registered Enterprises in Myanmar in 2004

\begin{tabular}{|l|c|c|}
\hline \multicolumn{1}{|c|}{ Category (Workers) } & Number & Share (\%) \\
\hline Small (10-50) & 33,863 & 78.0 \\
\hline Medium (50-100) & 6,359 & 14.6 \\
\hline Large (100+) & 3,213 & 7.4 \\
\hline Total & 43,435 & 100.0 \\
\hline
\end{tabular}

Source: Ministry of Industries, Myanmar as in Mandal (2007)

Distribution of SMEs by industries is presented in Table 3.

Table 3: Distribution of SMEs by Industries in 2006

\begin{tabular}{|l|c|c|c|c|c|}
\hline Industry & Small & Medium & Large & Total & \% \\
\hline Foodstuff & 22,003 & 3,659 & 1,765 & 27,427 & 63.3 \\
\hline Clothing and apparel & 1,354 & 360 & 276 & 1,990 & 4.6 \\
\hline Construction materials & 2,413 & 536 & 499 & 3,448 & 8.0 \\
\hline Personal goods & 479 & 280 & 249 & 1,008 & 2.3 \\
\hline Household goods & 122 & 90 & 104 & 346 & 0.8 \\
\hline Printing \& publishing & 243 & 98 & 20 & 361 & 0.8 \\
\hline Industrial raw materials & 650 & 278 & 97 & 1,025 & 2.4 \\
\hline Minerals \& mining & 1,201 & 429 & 188 & 1.818 & 4.2 \\
\hline Agricultural equipment & 36 & 20 & 9 & 64 & 0.1 \\
\hline Industrial equipment & 204 & 48 & 11 & 263 & 0.6 \\
\hline Transport vehicles & 65 & 18 & 56 & 139 & 0.3 \\
\hline Electrical goods & 12 & 12 & 34 & 58 & 0.1 \\
\hline Miscellaneous & 4,674 & 615 & 145 & 5,434 & 12.5 \\
\hline Total & 33,456 & 6,443 & 3,452 & 43.351 & $100 \%$ \\
\hline & $(77 \%)$ & $(15 \%)$ & $(8 \%)$ & $(100 \%)$ & \\
\hline
\end{tabular}

Source: Khin and Htwe, 2007

Growth of SMEs in Myanmar from 2002 to 2006 is summarized in Table 4.

Table 4: Growth of SMEs 2004-2006

\begin{tabular}{|l|c|c|c|c|c|}
\hline \multicolumn{1}{|c|}{ Size } & $\mathbf{2 0 0 2}$ & $\mathbf{2 0 0 3}$ & $\mathbf{2 0 0 4}$ & $\mathbf{2 0 0 5}$ & $\mathbf{2 0 0 6}$ \\
\hline Small & 31,852 & 33,454 & 33,863 & 33,456 & 33,455 \\
& & $5.0 \%$ & $1.2 \%$ & $-1.2 \%$ & $0.0 \%$ \\
\hline Medium & 4,342 & 6,215 & 6,359 & 6,430 & 6,479 \\
& & $43.1 \%$ & $2.3 \%$ & $1.1 \%$ & $0.8 \%$ \\
\hline Large & 2,304 & 3,135 & 3,213 & 3,438 & 3,462 \\
& & $36.1 \%$ & $2.5 \%$ & $7.0 \%$ & $0.7 \%$ \\
\hline Total & 38,498 & 42,804 & 43,435 & 43,324 & 43.396 \\
& & 11.25 & $1.5 \%$ & $-0.3 \%$ & $0.2 \%$ \\
\hline
\end{tabular}

Source: Khin and Htwe, 2007 
Kudo's (2002) study of young entrepreneurs found that access to finance, effects of culture and limited exposure, high inflation rate, and competition were major problems faced by entrepreneurs. Another survey in 2003 (Htein) and one in 2007 (Aung Kyaw) found similar impediments to SME growth - shortage of capital, shortage of skilled labor, and shortage of power. The Myanmar government itself has acknowledged that SME development does require serious attention as it is a critical component of the country's economy. The challenges faced by SMEs in Myanmar are similar to those faced by other developing nations. Kyaw Zaw, Deputy Director General of the Directorate of Investment and Company Administration, Ministry of National Planning and Economic Development, in his presentation to the ASEAN-Japan Seminar on FDI: Sharing Japanese SMEs Dynamism in ASEAN's Integration" in 2007, cited the following challenges that SMEs faced:

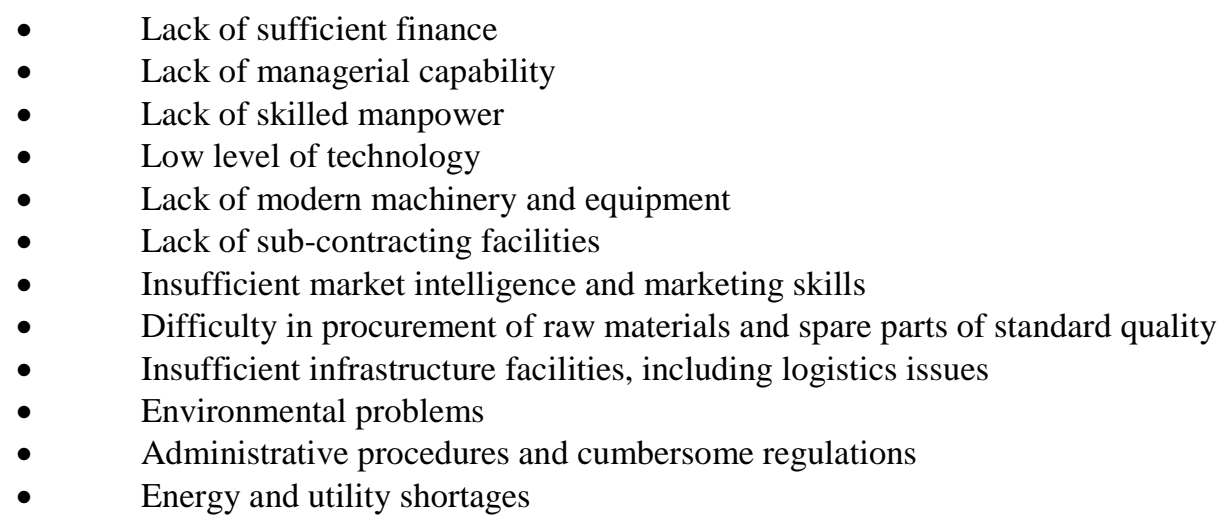

The government feels that it has recognized the need to participate actively in promoting the development of SMEs, but only recently, and intends to pursue this goal by giving it governmental and non-governmental focus.

\section{POLICY CONSIDERATIONS FOR MYANMAR}

As a prelude to discussing policy considerations, it is necessary that the share and value of SME contribution to Myanmar's economy is well understood. Even though SMEs contribution to the country is large, it is only to the industrial sector of the economy, which remains the smallest at $19.8 \%$. Agriculture is the largest sector accounting for $42.9 \%$ of the GDP and Services comes in second at $37.3 \%$. In terms of employment, agriculture provides $70 \%$, services $23 \%$, and industry employs only $7 \%$ of the labor force (CIA, 2010). The major industries that contributed to the GDP in 2006 were manufacturing (11.4\%), mining $(0.4 \%)$, energy $(0.2 \%)$, electricity $(0.1 \%)$, and others $(3.1 \%)$. With regard to SMEs' participation by sectors, the food and beverage industry accounted for about $75 \%$ of total industrial output (Kan Zaw, 2006), yet SMEs remain the key agent for Myanmar's industrialization. Though they always start small, they have the potential of growing into large businesses. They are also mostly private enterprises. Their growth truly reflects the growth of the private sector. "The development of the entrepreneurship spirit is highly associated with the development of SMEs as these are formed and run by entrepreneurs" (Aung Kyaw, 2008). SMEs are also important for the structural change of a country from being agriculture based to industrial and service-oriented.

Thus, it becomes imperative that the economic development of the country is directly dependent on the adoption of the free market system. Hence, there is a need to liberalize the economy, remove state monopolies and allow free enterprise, support export development, and create the infrastructure to allow this to take place. This in turn will stimulate the growth of SMEs as active participants in the economy. The existing system in Myanmar is far from this. The economy "suffers from serious macroeconomic imbalances" and "the business climate is widely perceived as opaque, corrupt and highly inefficient." Better investment and business climates and an improved political situation are needed. The government continues to exercise pervasive controls, the overall economic policies are inefficient, the poor investment climate hampers foreign investment, access to credit is very limited, and the country operates under very tight sanctions from the United States, the European Union, Canada and Australia (CIA, 2010). 
Myanmar is not ranked in the World Bank's 2010 Ease of Doing Business Survey, the World Economic Forum's 2009-2010 Competitiveness Index. It is ranked 175 out of 179 in the Heritage Foundation's Economic Freedom Index, 99 of 141 in the UNCTAD Inward Potential Performance Index, and 139 of 141 in the Fraser's Institute's Economic Freedom of the World Index. The country is ranked 138 of 182 in the 2009 United Nations Development Program's Human Development Index. Myanmar is one of the 31 countries in food crisis requiring external assistance as defined by the Food and Agriculture Organization (FAO). The International Food Policy Research Institute places Myanmar 53 out of 84 countries in the 2009 Global Hunger Index (eStandards, 2010). The country has remained isolated for an extended period of time. The World Bank has not approved lending for Myanmar since 1987. The country is in arrears in its repayments to the World Bank. There has been no direct assistance from the Asian Development Bank (ADB) in over 20 years. These are clear indicators that Myanmar's efforts toward achieving its economic development goals leave a lot to be desired. The country remains one of the least developed and poorest nations. The poverty incidence is estimated between $26.6 \%$ and $32.7 \%$ (CIA, 2007; ADB, 2008). It has the least open economy in Asia. The Financial Standards Foundation, in its 2010 Country Brief on Myanmar, finds the following areas requiring attention:

- The country's infrastructure is poorly developed. Much of it is old and decrepit. This includes roads, railways, ports, airports, water and sanitation systems.

- $\quad$ The country's economic statistics and trade data are unreliable.

- $\quad$ The country has a huge external debt (\$ 7.373 billion end of 2009) and budget deficit (4.5\% of GDP in 2009). Low revenues and high expenditures (estimated $40 \%$ is for defense) and heavy losses by state enterprises are causes. Inflation in 2007 was estimated to be $30 \%$ (ADB, 2008)

- The informal economy, which includes a huge black market, is very large. Smuggling is rampant, as is illicit drug trafficking. Myanmar is also the second largest producer of opium in the world, after Afghanistan.

- $\quad$ The financial system is fully controlled by the government, which sets interest rate. Banks are mainly fully or partially state owned. The few private banks are limited in their scope of operations.

- $\quad$ The currency (Kyat) is non-convertible and non-negotiable outside of Myanmar.

- $\quad$ There is a multiple exchange rate system. The official exchange rate of the kyat is 6.56 to the US dollar but market rates range from 900 to 1,000 .

- $\quad$ Corruption is rampant and the judiciary is not independent. Myanmar is ranked 178 of 180 countries in Transparency International's 2009 Corruption Perceptions Index. Most people view corruption as normal practice and requirement for survival.

- Myanmar does not offer a friendly environment to foreign investors. Many sectors are reserved for state enterprises - telecommunications, air and rail transport, broadcasting and television, exploration and production of petroleum, banking and insurance services, and export of precious stones.

- Tax rates are very high. Corporate tax rate is 30\%. There is a withholding tax of $15 \%$ on interest and royalties (for non-residents, it is 20\%). Foreign companies must pay their taxes in US dollars at the inflated exchange rate. Personal income tax ranges from 3\% to 30\% for residents and 5\% to 40\% for non-residents.

- Human capital is weak. The country lacks skilled labor and access to technology.

Myanmar has survived on its agricultural sector which contributed 44\% to the GDP, as well as export of natural gas, which contributed $20 \%$ of GDP. Fiscal deficits have been financed by central bank money creation. In order to rectify this trend, it is imperative that badly needed reforms are initiated. The ADB strongly recommends:

- Further liberalization of agriculture, domestic trade, and privatization of state enterprises to promote growth

- $\quad$ Development of banking and the creation of a domestic bond market to address deficits

- $\quad$ Creation of a unified exchange rate to reduce pricing distortions

- Improvement of the environment for private sector development to stimulate growth and employment

- Higher standards of governance and transparency to create a better business climate

- Improve availability of reliable data to allow for greater economic assessment and serve as a base for enhanced policy-making. 
These economic reforms can form the template for the development of the industrial sector and create an environment for SME growth. They are unequivocally interrelated. Priority must therefore be given to removing economic controls, encouraging foreign and local investment and exports, removing structural impediments to entrepreneurship, encouraging and facilitating the use of technology, improving skills development through education and training, providing all forms of access to credit, and improving the country's infrastructure. Overall, economic policy has to include an enabling environment for SMEs. This sector has to be given very serious consideration and priority. A comprehensive and effective strategy has to be developed to address the following urgent issues:

- Provide assistance in the areas of information, management, financing, mechanization, packaging, promotion, export, distribution, and technology

- $\quad$ Use global benchmarks to set goals and targets for SME development

- $\quad$ Seek support and help from regional and international organizations, such as ASEAN, ADB, and WB, to help develop and implement the policy

\section{CONCLUSION AND RECOMMENDATIONS}

Myanmar's economy is described by critics as the least open economy in Asia. It suffers from pervasive government controls, inefficient economic policy, and extensive poverty. Despite Myanmar's increasing hydrocarbons revenue, the social and economic environments have deteriorated because of the regime's mismanagement or corruption of its economy and it suffers from major economic imbalances, including rising inflation rates, financial deficits, multiple official exchange rates that overvalue the Burmese kyat, a distorted national interest rate regime, unreliable statistics and indicators, and an inability to reconcile national accounts to determine a realistic Gross Domestic Product (GDP) figure." The economy has survived mainly due to agriculture and mineral exports. The contribution of trade to the GDP has remained very low. Total exports in 2009 were $\$ 6.504$ billion and imports were $\$ 3.555$ billion (CIA, 2010). Main exports are natural gas, wood products (mainly teak), pulses and beans, fish, rice, clothing, and gems and were to Thailand (52.3\%), India (12.7\%), China (8.9\%), and Japan (4.4\%). Main imports are petroleum products and crude oil, fertilizer, plastics, machinery, transport equipment, cement and construction materials, and food products and edible oil. Major import partners are China (31.9\%), Thailand (21.2\%), Singapore (20.7\%), Malaysia (5.1\%), and Indonesia (4\%). FDI inflows have remained very poor at $\$ 258$ million in 2007 and $\$ 283$ million in 2008. These have been mainly in the oil and gas sector, tourism, and garment manufacturing. Per capita GDP remained at $\$ 442$, which is $\$ 1,200$ calculated at Purchasing Power Parity (PPP) in 2009 (Global Finance, 2010). The economic outlook for Myanmar does not look very promising when compared to other countries in the region and members of the Association of Southeast Asian Nations (ASEAN) in which Myanmar became a member in 1997. GDP forecast for the coming years, projected by the IMF, is shown in Table 5.

Table 5: Myanmar GDP Growth 2008-2014

\begin{tabular}{|c|c|c|c|c|c|c|}
\hline Year & $\mathbf{2 0 0 9}$ & $\mathbf{2 0 1 0}$ & $\mathbf{2 0 1 1}$ & $\mathbf{2 0 1 2}$ & $\mathbf{2 0 1 3}$ & $\mathbf{2 0 1 4}$ \\
\hline GDP & $4.26 \%$ & $5.03 \%$ & $5.03 \%$ & $5.04 \%$ & $5.05 \%$ & $5.06 \%$ \\
\hline
\end{tabular}

Source: IMF: World Economic Outlook Database, October 2009

If Myanmar is serious about developing its economy, it is imperative that liberalizing the economy and promoting private enterprise and investment need urgent addressing. SMEs can become a strong tool in this and the government must take immediate steps to develop a comprehensive program to encourage the growth of SMEs. This includes the creation of infrastructure for coordinating SME support, SME financing mechanism, development of human resources, export development, technology transfer, and adoption of relevant best practices, networking, good governance, and commitment of key policy makers. Much can be learned from other members of ASEAN, such as Singapore, Malaysia and Thailand, that have succeeded in similar endeavors. Table 6 illustrates the position of Myanmar within the regional pact of ASEAN in terms of its share of inward FDI. Myanmar stands to gain only $0.44 \%$, even amongst its own partners sharing a regional agreement that pervades international trade. This emphasizes the need for the country to develop an environment that is congenial for receiving international institutional investments. ASEAN policies toward SME development indicate certain incentives granted to local 
SMEs in Myanmar which include basic allowances, depreciation allowance, and rights to set off and/or carry forward losses to encounter reduced direct taxation.

Table 6: FDI Net Inflow in ASEAN Countries (as of 15 July 2010)

\begin{tabular}{|l|c|c|c|c|}
\hline \multicolumn{1}{|c}{ Country } & $\begin{array}{c}\text { FDI Net Inflow (in } \\
\text { millions of dollars) }\end{array}$ & $\begin{array}{c}\text { Of which Intra- } \\
\text { ASEAN (in millions } \\
\text { of dollars) }\end{array}$ & $\begin{array}{c}\text { Share to total } \\
\text { net inflow (\%) }\end{array}$ & $\begin{array}{c}\text { Of which Intra- } \\
\text { ASEAN (\%) }\end{array}$ \\
\hline Brunei Darussalam & 176.8 & 0.1 & $0.45 \%$ & $0.00 \%$ \\
\hline Cambodia & 530.2 & 170.8 & $1.34 \%$ & $3.86 \%$ \\
\hline Indonesia & $4,876.8$ & $1,380.1$ & $12.31 \%$ & $31.16 \%$ \\
\hline Lao PDR & 318.6 & 57.3 & $0.80 \%$ & $1.29 \%$ \\
\hline Malaysia & $1,381.0$ & $(269.7)$ & $3.48 \%$ & $-6.09 \%$ \\
\hline Myanmar & $\mathbf{5 7 8 . 6}$ & 19.5 & $1.46 \%$ & $0.44 \%$ \\
\hline The Philippines & $1,948.0$ & 18.7 & $4.92 \%$ & $0.42 \%$ \\
\hline Singapore & $16,256.2$ & $2,037.6$ & $41.02 \%$ & $46.01 \%$ \\
\hline Thailad & $5,965.9$ & 585.8 & $15.05 \%$ & $13.23 \%$ \\
\hline Vietnam & $7,600.0$ & 428.7 & $19.18 \%$ & $9.68 \%$ \\
\hline
\end{tabular}

Source: Table 25 ASEAN Statistics

\section{AUTHOR INFORMATION}

Dr. Balbir B. Bhasin serves as Ross Pendergraft Endowed Professor of International Business in the University of Arkansas, Fort Smith, Arkansas. He holds a Master of International Management (M.I.M.) degree from Thunderbird School of Global Management, Glendale, Arizona and a Ph.D. in International Business from the University of South Australia, Adelaide, Australia. He was the president of a private investment bank in New York, and CEO of an international business information company in the Far East. His research interests are in cross-cultural studies and FDI in Asian markets. He advises companies on opportunities in Emerging Asia. E-mail: balbir.bhasin@uafs.edu

Dr. Sivakumar Venkataramany serves as Professor of International Business in the Dauch College of Business \& Economics at Ashland University, Ashland, Ohio where he teaches global management and global finance. . He received his MBA, MS and Ph.D. from the University of Miami, Coral Gables, Florida. His research interests are risk management in global banks, emerging financial markets and FDI in developing economies. He has several teaching commitments abroad and serves as an examiner for doctoral theses. E-mail: Svenkata@ashland.edu. Corresponding author.

\section{REFERENCES}

1. Asian Development Bank: Fact Sheet for Myanmar, as of 31 December 2008.

2. Aung Kyaw (2007) "A Survey of SMEs in Selected Yangon Industrial Zones" Working Paper, 2007.

3. Aung Kyaw (2008) "Financing Small and Medium Enterprises in Myanmar", Institute of Developing Economies, IDE Discussion paper No. 148, April 2008.

4. $\quad$ Central Intelligence Agency: The World Factbook 2010.

5. eStandards (2010) Country Brief: Myanmar, eStandards Forum for the Financial Standards Foundation, New York. Accessed on February 19, 2010 at www.estandardsforum.org

6. EconomyWatch (2010) "Myanmar Economy by EconomyWatch", Economy, Investment and Finance Reports at www.economywatch.com.

7. Global Finance (2010) "Myanmar Country Report: GDP data and GDP forecasts; economic, financial and trade information; the best banks in Myanmar; country and population overview" Global Finance Magazine at http://www.gfmag.com/

8. Kan Zaw (2006) "Chapter 12: Challenges, Prospects and Strategies for CLMV Development: The Case of Myanmar", Economic Research Institute for ASEAN and East Asia accessed on April 23, 2010 at www.eria.org. 
9. Khin Maung Than and Htwe Htwe Win (2007) "Country Report - Union of Myanmar" presented to the Asian development Bank Institute (ADBI) on 14-19 March 2007 in Japan.

10. Kudo T. (2002) "Industrial Development in Myanmar: Prospects and Challenges" ASDEP No. 64 IDEJETRO, Chiba, Japan 2002.

11. Kudo T. and Mieno F. (2007) “Trade, Foreign Investment and Myanmar's Economic Development during the Transition to an open Economy", Institute of Developing Economies, IDE Discussion paper No. 116, August 2007.

12. Mandal, T. (2007) "SMEs in BIMSTEC: Synergies for Emerging Issues for Cooperation", Center for Studies in International Relations and Development CSIRD) Kolkata, January 2007.

13. Tin Maung Maung Than (2007) "State Dominance in Mayanmar: The Political Economy of Industrialization", Institute of Southeast Asian Studies, ISEAS Publishing, Singapore 2007.

14. Tin Soe (2008) "Policy Dilemmas and Economic Development: A Case Study of Myanmar Economy in Transition", Journal of International Cooperation Studies, Vol. 5 No. 3, 2008. 
NOTES 